\title{
Effect of Plant Growth Regulators on Growth and Yield Attributes of Tomato (Solanum lycopersicom Mill.)
}

\author{
Jyoti Singh $^{1}{ }^{*}$, A.K. Dwivedi ${ }^{1}$, Poornima Devi ${ }^{1}$, Jyoti Bajeli ${ }^{2}$, \\ Arunima Tripathi ${ }^{2}$ and Sunil Kumar Maurya ${ }^{1}$ \\ ${ }^{1}$ Department of Horticulture, Chandra Shekhar Azad University of Agriculture and \\ Technology, Kanpur Uttar Pradesh, India-208002 \\ ${ }^{2}$ Section of Horticulture, RMD College of Agriculture and Research Station, IGKV, \\ Ambikapur Chhattisgarh, India-497001
}

*Corresponding author

A B S T R A C T

\begin{tabular}{l} 
Key w or d s \\
Tomato, GA3, \\
NAA, 2,4-D, Fruit \\
yield \\
\hline Article Info \\
$\begin{array}{l}\text { Accepted: } \\
\text { 12 December } 2018 \\
\text { Available Online: } \\
\text { 10 January } 2019\end{array}$ \\
\hline
\end{tabular}

\section{Introduction}

Tomato (Lycopersicon esculentum Mill.) is commercially important throughout the world both for fresh fruit market and for the processing industries. India occupies a prime rank in vegetable production and is the second largest producer of vegetable next to China. The production of tomato in India is next to potato which is about 18 thousand million tonnes from an area of 0.8 million hectares (National Horticulture Board, 2015-16).
An experiment was conducted at Horticulture Garden, Department of Horticulture, Chandra Shekhar Azad University of Agriculture \& Technology, Kanpur during the Kharif season of 2016-2017. The experiment was laid out in Randomized Block Design with ten treatments in three replication consist of three levels of each growth regulator i.e. $\mathrm{GA}_{3}$ at 10, 20, $30 \mathrm{ppm}$, NAA at 20,30, $40 \mathrm{ppm}$ and 2,4-D at 2.5, 5.0, 7.5 ppm. Maximum plant height $(96.18 \mathrm{~cm})$, maximum number of primary and secondary branches, and maximum fruit per plant (46.06), fruit yield per plant (1320.0 g) and fruit yield per hectare $(52.5 \mathrm{t} / \mathrm{ha})$ as observed with the application of $\mathrm{GA}_{3}$ at $30 \mathrm{ppm}$. However, maximum number of flowers was obtained with the application of 2,4-D (5 ppm). The results indicated that the use of $\mathrm{GA}_{3}$ at specific concentration of $30 \mathrm{ppm}$, considerably increased the weight of fruit and significantly increased total yield up to $52.5 \mathrm{t} / \mathrm{h}$. 
order to improve the quantitative and qualitative characters of this precious vegetable, use of plant growth regulators is being encouraged to harness the superior quality of fruits.

Plant growth regulators (PGR) play a major role in plant growth and development. Growth of plant is directly related to the yield. The specific quantity of PGR in the plants is directly responsible for the promotion, inhibition or otherwise modification in the physiological processes. Since, higher concentrations of NAA inhibit growth and exert toxic effects on the plants. Therefore, optimum concentrations are required to determine the beneficial effects of NAA. The positive effects of NAA have been observed mainly in cell elongation, improvement of phototropism, formation of apical bud, respiration and initiation of flower bud. Similarly, gibberellin is also one of the most important growth stimulating substances used in tomato. This supports shoot growth by accelerating cell elongation and cell division in the sub apical meristematic region that results into enlargement of internodal length and also regulates the mitotic activity of the sub apical meristem (Davies, 2004). Several synthetic plant growth regulators were also tested to determine whether they could be used in solving this problem of high temperature for tomato production. Application of 2, 4-D increases fruit size, fruit set and accelerates fruit ripening (Vendrell, 1985). Though, it reduces the plant height, inter nodal length, days to flowering, acidity and number of seeds per fruits, but it significantly increases fruit set, number of fruits, TSS, number of secondary roots and yield. Therefore, these PGRs are used extensively in tomato to enhance yield by improving fruit set, size and number of fruits (Serrani, 2007). Therefore, in this study, investigations were carried out on the effect of plant growth regulators on the growth and yield attributes of tomato.

\section{Materials and Methods}

The experiment was conducted during the Rabi season of 2016-17 at Horticulture Garden, Chandra Shekhar Azad University of Agriculture and Technology, Kanpur. Geographically, Kanpur is situated in the alluvial belt of Gangatic plains of central Uttar Pradesh at an altitude of $126 \mathrm{~m}$. The location is subjected to extreme of weather conditions. The climate of region is subtropical with maximum temperature ranging from $23^{\circ} \mathrm{C}$ to $45^{\circ} \mathrm{C}$ in summer, minimum temperature ranging from $5.5^{\circ} \mathrm{C}$ to $13^{\circ} \mathrm{C}$ in winter and relative humidity ranging from $45-55 \%$ in different season of the year. The experiment was laid out in Randomized Block Design with three replications on tomato variety 'Azad T-6'. Seedlings were transplanted in November, 2016 at a spacing of $60 \times 40 \mathrm{~cm}$. A total of 9 treatments using three different concentration of each growth regulator viz., 2, 4-D@ 2.5 ppm, 5.0 ppm and 7.5 ppm GA 3 @ 10 ppm, 20 ppm, 30 ppm and NAA @ 20 ppm, $30 \mathrm{ppm}$ and $40 \mathrm{ppm}$ were used in the study. A total of seven distinguishing parameters namely, plant height, number of primary and secondary branches at different time period, number of flowers, number of fruit per plant, fruit yield per plant and fruit yield per hectare of tomato plants were taken during the experiment procedure. Statistical analysis of the data was done by using Analysis of Variance (ANOVA) technique and difference among treatment means were compared by using Duncan's Multiple Range (DMR) test at $5 \%$ level of probability (Steel et al., 1997).

\section{Results and Discussion}

\section{Morphological characters}

\section{Plant height (cm)}

The results of foliar application of PGRs viz., $\mathrm{GA}_{3}, \mathrm{NAA}$ and 2,4-D are summarized in the 
Table 1. The results evidence that use of $\mathrm{GA}_{3}$ and NAA at higher doses had positive response to plant height. The data categorically registered that the maximum plant height of $96.18 \mathrm{~cm}$ followed by 85.35 $\mathrm{cm}$ was recorded with the application of $\mathrm{GA}_{3}$ @ 30 ppm and NAA @ 30 ppm, respectively. While, there was a gradual decline in plant height at lower concentration of $\mathrm{GA}_{3}$ and NAA but the application of 2,4-D at lower concentrations $(5 \mathrm{ppm})$ found to increase the plant height $(68.84 \mathrm{~cm})$. At higher concentration of 2,4-D @ $7.5 \mathrm{ppm}$, the plants could reach up to a height of $60.54 \mathrm{~cm} . \mathrm{GA}_{3}$ and NAA, when sprayed at higher concentration, increased plant height significantly as compared to control (68.19 $\mathrm{cm})$.

This increase in height may be due to the fact that the application of $\mathrm{GA}_{3}$ supporting vegetative growth by promoting active cell division and cell elongation that ultimately resulted into plant height. These results were in close agreement with the findings of Verma et al., (2014) and Uddain and Hossain (2009). The increment in the morphological parameters due to $\mathrm{GA}_{3}$ and NAA growth substances may be due to their effect on cell elongation, cell growth, respiration and nucleic acid metabolism.

The osmotic uptake of water and nutrients under the influence of $\mathrm{GA}_{3}$ which maintains a swelling force against the softening of cell walls or due to the stimulus exerted by the effect of $\mathrm{GA}_{3}$ in the soil and therefore, the plant height might have increased.

Higher doses of 2, 4-D had an adverse effect on the plant height. Herbicide nature of plant growth regulators as 2, 4-D might be the reason of retardation of plant height. These results are clearly in agreement with the substantial studies of Kumar et al., (2018), Tiwari and Singh (2014) and (Gelmesa et al., 2013).

\section{Number of primary and secondary branches}

Results regarding to the number of primary and secondary branches at different days of intervals are expressed in the Table 1. The table indicates that maximum numbers of branches were observed with the application of $\mathrm{GA}_{3} @ 30$ ppm, while, there was a declining trend at lower concentrations of $\mathrm{GA}_{3}$.

A similar progression was prevailed with the application of NAA, while, a reverse course was recorded with the application of 2, 4-D such as more number of branches, were recorded at lower concentration (5 ppm) at each interval. At 90 DAS, more number of primary and secondary branches was measured with $\mathrm{GA}_{3}$ at $30 \mathrm{ppm}$ (13) as compared to control (9). It was revealed by Ranjeet et al., (2014) that the number of branch per plant tomato increased with the use of plant growth regulators in tomato, particularly with the application of $\mathrm{GA}_{3} @ 30$ ppm. Similar trend of results was reported by Singh and Singh (2005).

\section{Yield and yield attributing characters}

\section{Number of flowers per plant}

Tomato is a day neutral vegetable but requires more number of sunny days to regulate flowering and fruiting.It is clear from Table 2 that the number of flowers per plant was significantly higher with the application of $\mathrm{GA}_{3}$ at $30 \mathrm{ppm}$. Lower concentrations of 2,4$\mathrm{D}$ at $5 \mathrm{ppm}$ also reflected higher number of flowers per plant.

The data clearly showed that higher number was recorded in concentrations of $\mathrm{GA}_{3}$ at 30 ppm (47.82) as compared to control (40.60). Lower concentration of 2, 4-D treatment at 5 ppm indicated a positive effect on flower 
count per plant (48.68). In case of NAA, increased concentration of NAA up to $30 \mathrm{ppm}$ (46.24) significantly influenced the tomato crop. Considerable dose of growth regulators is favorable for plant growth and it also augmented the flower count per plants. The higher concentration of $\mathrm{GA}_{3}$ at $30 \mathrm{ppm}$ had significantly enhanced the flower count per plants over lower levels of $\mathrm{GA}_{3}$. The possible causes could be the increased production of flower primodia in tomato.

Table.1 Effect of different concentrations of GA3, NAA and 2, 4-D on vegetative characters of tomato var. 'Azad T-6'

\begin{tabular}{|c|c|c|c|c|c|c|c|c|c|}
\hline \multirow[t]{2}{*}{ Sl.no. } & \multirow[t]{2}{*}{ Treatment } & \multirow{2}{*}{$\begin{array}{l}\text { Plant } \\
\text { Height } \\
\text { (cm) }\end{array}$} & \multicolumn{4}{|c|}{$\begin{array}{l}\text { Number of primary } \\
\text { branches }\end{array}$} & \multicolumn{3}{|c|}{$\begin{array}{l}\text { Number of secondary } \\
\text { branches }\end{array}$} \\
\hline & & & $\begin{array}{l}10 \\
\text { DAP }\end{array}$ & $\begin{array}{l}30 \\
\text { DAP }\end{array}$ & $\begin{array}{l}60 \\
\text { DAP }\end{array}$ & $\begin{array}{l}90 \\
\text { DAP }\end{array}$ & $\begin{array}{l}30 \\
\text { DAP }\end{array}$ & $\begin{array}{l}\text { 60DA } \\
P\end{array}$ & 90DAP \\
\hline 1. & Control & 68.19 & 2.80 & 4.50 & 7.40 & 8.90 & 1.25 & 5.45 & 8.15 \\
\hline 2. & $\mathrm{GA}_{3} @ 10 \mathrm{ppm}$ & 74.46 & 3.65 & 7.33 & 11.62 & 12.96 & 1.69 & 8.30 & 12.40 \\
\hline 3. & $\mathrm{GA}_{3} @ 20 \mathrm{ppm}$ & 94.53 & 3.72 & 7.45 & 11.68 & 13.30 & 1.76 & 8.60 & 12.64 \\
\hline 4. & $\mathrm{GA}_{3} @ 30 \mathrm{ppm}$ & 96.18 & 3.95 & 7.58 & 12.31 & 13.39 & 1.78 & 8.75 & 12.80 \\
\hline 5. & NAA@ @20ppm & 78.10 & 2.89 & 5.66 & 9.01 & 10.05 & 1.33 & 6.53 & 9.65 \\
\hline 6. & NAA@30 ppm & 85.35 & 3.30 & 6.75 & 10.66 & 11.85 & 1.54 & 7.57 & 11.50 \\
\hline 7. & NAA@ @ 40 ppm & 82.47 & 3.10 & 6.17 & 9.85 & 11.47 & 1.45 & 7.12 & 10.12 \\
\hline 8. & 2,4-D@ 2.5 ppm & 64.10 & 2.65 & 5.49 & 8.98 & 9.89 & 1.26 & 6.39 & 9.35 \\
\hline 9. & 2,4-D@ 5.0 ppm & 68.84 & 2.90 & 5.86 & 9.20 & 10.28 & 1.30 & 6.65 & 9.57 \\
\hline 10. & 2,4-D@7.5 ppm & 60.54 & 2.42 & 5.04 & 8.07 & 9.10 & 1.20 & 5.84 & 8.88 \\
\hline & $\mathrm{SE}(\mathrm{d} \pm)$ & 2.15 & 1.25 & 1.41 & 0.24 & 2.35 & 3.07 & 0.20 & 0.41 \\
\hline & $\mathrm{CD}$ & 4.52 & 0.43 & 0.87 & 1.40 & 1.56 & 0.81 & 1.00 & 1.34 \\
\hline
\end{tabular}

Table.2 Effect of different concentrations of GA3, NAA and 2, 4-D on yield characters of tomato var. 'Azad T-6'

\begin{tabular}{|c|c|c|c|c|c|}
\hline S.N. & Treatment & $\begin{array}{l}\text { Number of } \\
\text { fruit/plants }\end{array}$ & $\begin{array}{l}\text { Fruit yield } \\
\text { per plant (g) }\end{array}$ & $\begin{array}{l}\text { Fruit yield } \\
(\mathbf{q} / \mathbf{h})\end{array}$ & $\begin{array}{l}\text { Number of } \\
\text { flowers/plant }\end{array}$ \\
\hline 1. & Control & 22.03 & 890.0 & 345.60 & 40.60 \\
\hline 2. & $\mathrm{GA}_{3} @ 10$ ppm & 42.15 & 1265.0 & 510.20 & 45.86 \\
\hline 3. & $\mathrm{GA}_{3} @ 20 \mathrm{ppm}$ & 45.36 & 1288.0 & 512.00 & 47.46 \\
\hline 4. & $\mathrm{GA}_{3} @ 30 \mathrm{ppm}$ & 46.06 & 1320.0 & 525.00 & 47.82 \\
\hline 5. & NAA @20 ppm & 35.18 & 985.0 & 392.50 & 43.36 \\
\hline 6. & NAA @30 ppm & 41.46 & 1125.0 & 453.10 & 46.24 \\
\hline 7. & NAA @40 ppm & 38.45 & 1045.0 & 428.58 & 45.68 \\
\hline 8. & 2,4-D @2.5 ppm & 28.84 & 935.0 & 368.59 & 41.22 \\
\hline 9. & 2,4-D @5.0ppm & 30.93 & 1008.0 & 405.20 & 48.68 \\
\hline \multirow[t]{3}{*}{10.} & 2,4-D @7.5 ppm & 23.05 & 890.0 & 356.20 & 41.25 \\
\hline & SE (d) & 0.74 & 53.27 & 42.73 & 0.67 \\
\hline & $\mathrm{CD}$ & 2.98 & 111.96 & 89.81 & 2.63 \\
\hline
\end{tabular}


Various concentrations of $\mathrm{GA}_{3}$, NAA and 2, 4-D increased the number of flowers per plant clearly mark that these growth regulators contributed in regulating the physiological and biochemical process in plants in such a way which tended to reduce the vegetative growth and the photosynthates got transmitted from vegetative parts towards the reproductive organs. These results are in a clear agreement with the observations of Verma et al., (2014). However, the results were in disagreement with the result of Onofeghara (1983); Saleh and Abdul (1980), who observed less number of flowers at higher concentration. This might be due to the application of varying concentration of $\mathrm{GA}_{3}$.

\section{Number of fruits per plant (g)}

Increased flower count resulted into increased number of fruit per plant. Various concentrations of $\mathrm{GA}_{3}(10,20$ and $30 \mathrm{ppm})$ and NAA (20, 30 and $40 \mathrm{ppm}$ ) consequently increased the number of fruits per plant increased in a concentration dependent manner. Application of $\mathrm{GA}_{3}$ significantly increased the number of fruits per plant (46.06). This may be due to the characteristic effect of $\mathrm{GA}_{3}$ on fruit growth. Fruiting in tomato is governed by optimum concentration of growth regulator along with sufficient carbohydrates reserve. $\mathrm{GA}_{3}$ become more active with extra food reserve and hence the number of fruits seems to have increased. In case of NAA, highest number of fruit (41.26) was obtained with the application of NAA at $30 \mathrm{ppm}$. The 2, 4-D at minute concentration of $5 \mathrm{ppm}$ has very moderate effect in enhancing the number of fruits per plant (30.93) as compared to that of control (22.03). An increasing number of fruit as a result of $\mathrm{GA}_{3}$ application has also been obtained by Verma et al., (2014); Uddain and Hossain (2009). Higher levels of $\mathrm{GA}_{3}$ detected in young, immature tomato fruits (Koornneef $e t$ al., 1990) which may have attributed in anthesis, stimulate number of fruit, and seed development in tomato (Rebers et al., 1999).

\section{Fruit yield per plant}

Scrutiny of data summarized in Table 2 revealed that the maximum yield per plant was recorded with the application higher concentration of $\mathrm{GA}_{3}$ at $30 \mathrm{ppm}(1320 \mathrm{~g})$ as compared to control (890 g). The upsurge in yield may be due to the application of $\mathrm{GA}_{3}$ due to which the plant exerted increased physiological activities to build up adequate food reserve for producing more number of flowers, fruit and greater fruit set occurred, which ultimately manifested higher yield. A similar trend was noticed in case of NAA at higher concentration while reverse trend in 2 , 4-D at lower concentration. The result obtained by Uddain and Hossain (2009) are similar to the present finding. Beside this, other probable reason for the yield enhancement with applications of growth regulators might be due to better utilization of nutrients and photosynthates for the development of fruits in response to reduction of vegetative growth (Tiwari and Singh 2014). These findings are in accordance with the results of Kumar et al., (2018), Ranjeet et al., (2014) and Uddain et al., (2009).

\section{Fruit yield (q/ha)}

The result related to fruit yield per ha is presented in the Table 2. The maximum yield of (52.5 t/ha) was produced by $\mathrm{GA}_{3}$ at $30 \mathrm{ppm}$ concentration as compared to control (34.56 t/ha). Yield is considered to be an ultimate expression of both the physiological and metabolic activities of plants and is governed by a number of factors such as promising nature of soil including physical, chemical and biological properties and role of effective plant growth regulators causing morpho- 
physiological and biochemical changes that occur in the plants. The effect of higher level of $\mathrm{GA}_{3}$ might be due to the fact that it acts as a stimulus on root and shoot growth which might have contributed to more absorption and translocation of nutrients and also played physiological role in order to enhance the process of photosynthesis to build up sufficient food stocks for developing flowers, fruit and resulted in increased fruit set, which ultimately led to higher yields. A similar pattern was followed in case of NAA but a reverse trend was observed on application of 2,4-D.These finding lend their support from the substantial studies done by Ranjeet et al., (2014) and Kumar et al., (2014).

In conclusion, investigations of the present study indicate that the effect of various plant growth regulators $\mathrm{GA}_{3}$, NAA and 2,4-D at specific concentrations $\left(\mathrm{GA}_{3}\right.$ at $30 \mathrm{ppm}, \mathrm{NAA}$ at $30 \mathrm{ppm}$ and $2,4-\mathrm{D}$ at $5 \mathrm{ppm}$ ) considerably increased the weight of fruit and significantly increases total yield up to $525.0 \mathrm{q} / \mathrm{ha}$ of tomato. $\mathrm{GA}_{3}$ played a major role in increasing the plant height and number of branches per plant, which are ultimately related to the yield attributes of plant. 2,4- D significantly reduced the length of internode, days to flowering, but it enhanced the fruit set, number of fruits, TSS, number of secondary braches and yield. Hence, it can be concluded that different doses of $\mathrm{GA}_{3}$, NAA and 2,4-D at specific concentrations $\left(\mathrm{GA}_{3}\right.$ at $30 \mathrm{ppm}$, NAA at $30 \mathrm{ppm}$ and 2,4-D at $5 \mathrm{ppm}$ ) could be used to improve the morphological and yield attributing characters of tomato.

\section{References}

Gelmesa, D., Abebie B. and Desalegn, L, 2013. Effects of Gibberellic Acid and 2,4 Dichlorophenoxy Acetic Acid spray on vegetative growth, fruit anatomy and seed setting of tomato (Lycopersicon esculentum Mill.), Sci. Technol. Arts
Res. J., 2(3): 25-34.

Horticultural Statistics at a glance 2017. Horticulture Statistics Division Department of Agriculture, Cooperation \& Farmers Welfare Ministry of Agriculture \& Farmers Welfare Government of India (National Horticulture Board, 2015-16).

Kumar S., Singh R., Singh, V. Singh, M.K. and Singh A.K. 2018. Effect of plant growth regulators on growth, flowering, yield and quality of tomato (Solanum $\begin{array}{lll}\text { lycopersicum } & \text { L.). Journal of }\end{array}$ Pharmacognosy and Phytochemistry, 7(1): 41-44.

Onofeghara, F.A., 1983. The effect of growth substances on flowering and fruiting of Lycopersicon esculentum and Vigna unguiculata. Phytol. Argentina, 40(1): 107-116.

Peter J. Davied 2004. Plant hormones biosynthesis, signal transduction, action. Kluwer Academic Publishers. ISBN 14020-2686-2 (e-Book). $3^{\text {rd }}$ Edition 2004.

Ranjeet, Ram, R. B., Prakash, J. and Meena, M. L. 2014. Growth, flowering, fruiting, yield and quality of tomato (Lycopersicon esculentum Mill.) as influenced plant bio regulators. International Journal of Plant Sciences. 9 (1): 67-71.

Saleh, M.M.S. and Abdul, K.S. 1980. Effect of gibberellic acid and cycocel on growth, flowering and fruiting of tomato (Lycopersicon esculentum) plants. Mesopotamia J. Agric., 15(1): 137-166.

Serrani, J.C., M. Fos, A. Atare's and J.L. Garc'a Mart'nez, 2007. Effect of gibberellin and auxin on parthenocarpic fruit growth induction in the cv MicroTom of tomato. J. Plant Growth Regul., 26: 211-221.

Singh S. K. and Kumar A. 2018. Effect of Naphthalene Acetic Acid (NAA) and 
Gibberellic Acid (GA3) on Growth and Fruit Quality of Tomato (Lycopersicon esculentum Mill.) Int.J.Curr. Microbiol. App. Sci (2018) 7(3): 306-311.

Singh, B.K., Kumar, V., Singh, A.K. and Rai, V.K. 2011. Role of NAA on growth, yield, and quality of tomato (Lycopersicon esculentum Mill.) cultivars. Environment and Ecology, 29(3): 1091-1093.

Tiwari, A. K. and Singh, D. K. 2014. Use of plant growth regulators in tomato (Solanum lycopersicum L.) under tarai conditions of Uttarkhand. Indian Journal of Hill Farming, 27(2):38-40. and Rahman, MJ. 2009. Effect of different plant growth regulators on growth and yield of tomato. International Journal of Sustainable Agriculture, 1(3): 58-63.

Vendrell, M. 1985. Dual effect of 2,4-D on ethylene production and ripening of tomato fruit tissue. - Physiol. Plant. 64: 559-563.

Verma, P.P.S., Meena, M. L. and Meena, S.K. 2014. Influence of plant growth regulators on growth, flowering and quality of tomato (Lycopersicon esculentum Mill), cv. H-86. Indian Journal of Hill Farming, 27(2): 19-22.

Uddain, J., Hossain, KMA., Mostafa, MG.

\section{How to cite this article:}

Jyoti Singh, A.K. Dwivedi, Poornima Devi, Jyoti Bajeli, Arunima Tripathi and Sunil Kumar Maurya. 2019. Effect of Plant Growth Regulators on Growth and Yield Attributes of Tomato (Solanum lycopersicom Mill.). Int.J.Curr.Microbiol.App.Sci. 8(01): 1635-1641. doi: https://doi.org/10.20546/ijcmas.2019.801.171 